\title{
Financial Market Participation Of Immigrants And Native-Born Americans: The Role Of Income Uncertainty
}

Swarn Chatterjee, University of Georgia, Athens, USA

\begin{abstract}
This paper uses the National Longitudinal Survey dataset to examine the role of income uncertainty in explaining the likelihood of financial asset ownership among native-born and immigrant Americans. After controlling for a number of socioeconomic, demographic and behavioral factors, the results suggest that individual investors who face greater income uncertainty are less likely to own financial assets. This relationship holds true for immigrants and native-born Americans. Additionally, the likelihood of financial asset ownership increases with income, risk tolerance, and educational attainment for immigrants as well as for natives. Results also suggest that financial market participation among immigrants increases with the number of years they remain in the United States.
\end{abstract}

Keywords: Economic integration, Income Uncertainty, Investment Behavior.

\section{INTRODUCTION}

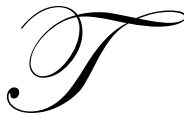

he extent of the financial market participation among immigrants is an issue of importance for economists, policy experts, and scholars of investor behavior and financial market participation. According to recent research estimates, one in every nine Americans is an immigrant (Osili \& Paulson, 2004). Recent studies on savings behavior of Americans find that immigrants save less than natives (Amudedo-Dorantes \& Pozo, 2002; Cobb-Clark \& Hildebrand, 2006) and immigrants are less likely to have checking or savings accounts (Osili \& Paulson, 2004). Financial asset ownership represents a certain level of sophistication in the individual's economic participation. Related literature on Canadian immigrants found that, although the immigrants saved less initially than their Canadian-born counterparts, this difference decreased with immigrants' economic integration into the Canadian society (Carroll, Rhee, and Rhee, 1994). This study uses the National Longitudinal Survey data set (NLSY79) to examine whether there is any disparity in financial market participation among immigrants and native-born Americans, and it determines whether income uncertainty of individual investors can affect their likelihood of owning financial assets such as mutual funds or stocks.

\section{REVIEW OF LITERATURE}

\section{Financial Asset Ownership}

Haliassos and Bertaut (1995) found in their research that approximately $75 \%$ of households in the U.S. did not own stocks. Another study found that financial market participation of households through investments in stocks, mutual funds, and retirement plans increased substantially between 1998 and 2001 (Aizcorbe, Kennickell, and Moore, 2003). Chapman, Dow, and Hariharan (2005) found that households responded to changes in stock market prices by shifting their investments between stock-based and non-stock-based assets. Previous studies also indicate that the level of stock ownership increased with educational attainment and income (Wang \& Hanna, 1997). Haurin, Hendershott, and Wachter (1996) found that each households' asset ownership is determined by income, the cost of acquiring assets, and borrowing constraints. Borjas (2002) found that, due to the lower average income of the more recent immigrants, the native-immigrant wealth gap has widened in recent years. 


\section{Immigrant Assimilation}

Carroll, Rhee, and Rhee (1999) found that U.S. immigrants accumulated wealth at a much faster rate between 1980 and 1990 than households of native U.S. citizens. This study also showed that immigrants consumed more and saved less than natives initially; however, this difference dissipated as their economic participation and access to investments grew over a period of approximately 25 to 30 years. Borjas (1985) found that immigrants' income grew rapidly with their assimilation into the United States. An early study by Chiswick (1978) indicates that immigrant income rose over time with their increasing labor market participation and the wage difference from the native-born American households disappeared after approximately 10 to 15 years of residence in the United States.

\section{Income Uncertainty}

According to the Amuedo-Dorantes and Pozo (2002) study, native-born Americans are more responsive to income uncertainty in their savings behavior than the immigrant Americans. Kazarosian (1997) found that individuals facing greater income uncertainty are likely to save a greater percentage of their permanent income. The Robst, Deitz, and McGoldrick (1998) study found that income uncertainty is negatively associated with ownership of housing wealth. Also in the context of investment in housing wealth, Henderson and Ioannides (1983) found that when investors face less income uncertainty, their investment demand is greater than their consumption demand; therefore, they are more likely to invest in asset ownership. Conversely, when investors face greater income uncertainty, they are less likely to invest in long-term assets and instead are more likely to use their income for present consumption.

\section{METHODOLOGY}

\section{The Theory of Income Uncertainty and Investment Demand}

The effect of income uncertainty on household investment behavior has been discussed in a number of studies. Previous studies by Henderson and Ioannides (1983, 1987); Fu (1991, 1995), and Robst et al. (1998) indicate that uncertainty of income among investors increases their risk aversion. As a result of this, investors tend to save less for future and increase their current consumption. Robst et al. (1998) have concluded that this shift in preference among investors facing income uncertainty also results in a greater demand for liquidity and reduces the likelihood of investment in risky assets or those that will tie up their future income over a longer period of time. Past studies provide empirical confirmation that a greater degree of uncertainty regarding future income reduces investment participation of households (Haurin \& Gill, 1987; Robst et al., 1998). Since financial market participation requires an investment decision to put money away in the form of stock equity or mutual funds to pay for future consumption, it is therefore hypothesized that preference for stock ownership or mutual fund investments will also decrease when income uncertainty increases among investors.

Past studies provide evidence of a negative association between cultural difference and amounts held in investment assets such as stocks (Carroll et al., 1994; Wang \& Hanna, 1997). Amuedo-Dorantes and Pozo (2002) provide evidence that income uncertainty affects wealth accumulation and market participation of individuals. Also, given the fact that financial asset ownership requires an understanding of the sophisticated American financial system and the ability to process the available investment information effectively, we hypothesize that:

Hypothesis 1: Immigrants are likely to have lower financial asset ownership than native-born Americans when controlling for other socioeconomic, financial, and demographic characteristics as well as risk tolerance

Hypothesis 2: Greater income uncertainty is likely to reduce investment participation in financial assets after controlling for other factors including risk tolerance

\section{Determining Income Uncertainty}

Income uncertainty is determined by following a technique suggested in a study by Robst et al. (1998). To determine income uncertainty, income for each year is regressed against socioeconomic and demographic 
characteristics. Residuals of annual income regressions from 1994 through 2004 are obtained. Uncertainty is equal to the standard deviation of the residual earnings. This method is comparable to the estimations of income uncertainty carried out previously in similar studies (Amuedo-Dorantes \& Pozo, 2002; Kazarosian, 1997).

\section{Measuring Risk Tolerance}

Previous studies indicate differences in risk tolerance between native-born and immigrant Americans (Amuedo-Dorantes \& Pozo, 2002; Barsky, Juster, Kimball, and Shapiro, 1997). Because of its association with financial asset ownership in previous studies, risk tolerance is included as a covariate in the model. The risk variable coincides with those created by Lusardi (1998) from the Health and Retirement Study (HRS) dataset and AmuedoDorantes and Pozo (2002) from the National Longitudinal Survey (NLSY) dataset.

\section{Variables}

The dependent variable for this study is ownership of stocks or mutual funds. This is a binary variable, coded as " 1 " if the respondent owns stocks or mutual funds and as " 0 " if otherwise. The key explanatory variable of interest is immigrant status (coded as " 1 " if the respondent is an immigrant and " 0 " if he or she is not an immigrant). Immigrants are defined as individuals who currently are American citizens but were born abroad to non U.S. parents before 1979. Other explanatory variables include income uncertainty, risk tolerance, demographics, and socioeconomic characteristics drawn from the NLSY79 data. Immigrant status is included among the explanatory variables to determine whether there exists native-immigrant disparity in terms of financial asset ownership. Among the demographic variables, age is included, because age has been determined to be a significant predictor of financial asset holdings (Haurin et al., 1996). Age squared is also included in the model because of its quadratic relationship with saving and investment decisions, as indicated in prior literature (Wang \& Hanna, 1997). Extant research has shown that Caucasians are more likely than minorities to hold high-risk and high-return assets (Keister, 2000). In order to control for this racial difference, Caucasian respondents have been used as the reference group. Blacks, Hispanics, and Asians are compared to Caucasians. Education, martial status, children, and gender are also included because of their association with investment participation in prior literature (Springstead \& Wilson, 2000; Zagorsky, 2005). Income and inheritance are included, since these variables are also found to be associated with asset ownership and savings practices (Amuedo-Dorantes \& Pozo, 2002; Menchik \& Jianakoplos, 1997; Osilli \& Paulson, 2004). The above model is then repeated to estimate for native-born and immigrant Americans separately.

\section{Data and Sample}

This study uses a dataset containing economic, social, demographic, and behavioral characteristics derived from the National Longitudinal Survey (NLSY79), data from a nationally representative panel composed of 12,686 respondents managed by the Center for Human Resource Research, Ohio State University. The 1979 wave began with a national survey of individuals born between 1957 and 1964. The NLSY79 has surveyed the same respondents between 1979 and 2004, across 21 waves of this panel in subsequent years. Zagorsky $(1997,1999)$ finds that the data contained in the NLSY correlates well with the wealth data in other major national databases such as the Survey of Consumer Finance (SCF), Panel Study of Income Dynamics (PSID), and Survey of Income and Program Participation (SIPP). The level of respondent retention has been close to 90\% (Haurin et al., 1996). This survey includes 874 immigrants born before 1979 outside the United States to parents not native to the U.S. Investment information for this study has been drawn from the 2004 wave, which contains the most recent detailed information on investments.

\section{Analysis}

This study examines the determinants of owning financial assets such as stocks or mutual funds and whether immigrant Americans differ significantly from the native-born Americans in their preference for ownership of these financial assets. Probit estimation technique is used for calculating the coefficients of the hypothesized and control variables. A descriptive statistical analysis is initially performed to examine the demographic composition, educational attainment, income, and investment preferences of natives and immigrants. The demographic characteristics include age, family size, gender, marital status, children, and race. Investment preferences included in 
the descriptive statistics composed of homeownership, preference for stock or mutual fund ownership, and money in bank accounts.

\section{RESULTS}

\section{Descriptive Statistics}

Table 1 shows the demographic and socioeconomic composition of the sample. The mean household income for natives $(\$ 64,626)$ is greater than that of immigrants $(\$ 61,087)$. The difference is more exaggerated in cases with financial assets holdings and those with bank accounts. In this study, $11.3 \%$ of immigrants participated in financial asset ownership (stocks or mutual funds), compared with 16.4\% for the native-born Americans. Also, $72 \%$ of immigrants have a bank account as compared to $77 \%$ of native-born Americans. Educational attainment, an influential factor in asset ownership, appeared to be much higher for native-born Americans as compared to that of immigrants.

Table 1

Descriptive Statistics

\begin{tabular}{|c|c|c|c|c|}
\hline Variables & & All & Native & Immigrant \\
\hline Age & Continuous & 42.8 & 42.8 & 43.1 \\
\hline Male & Equal to 1 if yes; 0 otherwise & $48.00 \%$ & $48.00 \%$ & $48.00 \%$ \\
\hline Married & Equal to 1 if yes; 0 otherwise & $36.00 \%$ & $35.00 \%$ & $37.00 \%$ \\
\hline \multicolumn{5}{|l|}{ Education } \\
\hline$<12$ years & Equal to 1 if yes; 0 otherwise & $12.00 \%$ & $9.90 \%$ & $23.70 \%$ \\
\hline 12 years & Equal to 1 if yes; 0 otherwise & $44.70 \%$ & $44.90 \%$ & $38.70 \%$ \\
\hline $13-15$ years & Equal to 1 if yes; 0 otherwise & $24.30 \%$ & $24.90 \%$ & $23.30 \%$ \\
\hline 16 years & Equal to 1 if yes; 0 otherwise & $12.00 \%$ & $12.50 \%$ & $8.30 \%$ \\
\hline$>16$ years & Equal to 1 if yes; 0 otherwise & $7.00 \%$ & $7.80 \%$ & $6.00 \%$ \\
\hline Family Size & Continuous & 3.1 & 3.1 & 3.4 \\
\hline Have Children & Equal to 1 if yes; 0 otherwise & $48.57 \%$ & $48.44 \%$ & $50.24 \%$ \\
\hline \multicolumn{5}{|c|}{1} \\
\hline White & Equal to 1 if yes; 0 otherwise & $59.10 \%$ & $61.10 \%$ & $32.80 \%$ \\
\hline Black & Equal to 1 if yes; 0 otherwise & $25.80 \%$ & $26.50 \%$ & $15.10 \%$ \\
\hline Hispanic & Equal to 1 if yes; 0 otherwise & $12.10 \%$ & $11.20 \%$ & $38.70 \%$ \\
\hline Asian & Equal to 1 if yes; 0 otherwise & $3.00 \%$ & $1.20 \%$ & $13.40 \%$ \\
\hline Household Income & Continuous & $\$ 64,384$ & $\$ 64,626$ & $\$ 61,087$ \\
\hline \multicolumn{5}{|l|}{ Years in US } \\
\hline $25-29$ years & Equal to 1 if yes; 0 otherwise & & & $24.80 \%$ \\
\hline $30-34$ years & Equal to 1 if yes; 0 otherwise & & & $27.30 \%$ \\
\hline 35-39 years & Equal to 1 if yes; 0 otherwise & & & $23.80 \%$ \\
\hline $40-44$ years & Equal to 1 if yes; 0 otherwise & & & $19.50 \%$ \\
\hline $45-47$ years & Equal to 1 if yes; 0 otherwise & & & $4.60 \%$ \\
\hline \multicolumn{5}{|l|}{ Investment Participation } \\
\hline Homeowner & Equal to 1 if yes; 0 otherwise & $69.30 \%$ & $69.40 \%$ & $64.10 \%$ \\
\hline Have Bank Accounts & Equal to 1 if yes; 0 otherwise & $76.20 \%$ & $77.00 \%$ & $72.10 \%$ \\
\hline Have Financial assets & Equal to 1 if yes; 0 otherwise & $16.30 \%$ & $16.40 \%$ & $11.30 \%$ \\
\hline
\end{tabular}

In Table 2, the tests of significance for financial market participation reveal that immigrants $(11.3 \%)$ are significantly less likely than native-born Americans (16.4\%) to own financial assets (stocks or mutual funds). Similarly, a much higher proportion of native-born Americans have bank accounts when compared with immigrants. Also, prevalence of homeownership (housing wealth) is higher for native-born Americans than for immigrants. Determinants of financial asset ownership 
Table 2

Test of Significance for Financial Market Participation

\begin{tabular}{ccccc}
\hline Variables & Native-born & Immigrants & T-test & Significance \\
\hline Own Financial Assets & 0.164 & 0.113 & 4.93 & $* * *$ \\
Have Bank Account & 0.770 & 0.721 & 2.99 & $* * *$ \\
Own Homes & 0.694 & 0.641 & 3.82 & $* * *$ \\
\hline
\end{tabular}

$* \mathrm{p}<.1, * * \mathrm{p}<.05, * * * \mathrm{p}<.01$

Table 3 shows the probit estimation results for the entire population (columns 1 through 3 ) as well as for native-born (columns 4 through 6) and immigrant (columns 7 through 9) groups. The results show that income uncertainty is a negative predictor of financial asset ownership in all three groups. This finding is consistent with the proposed model of this paper that income uncertainty reduces the likelihood of owning stocks or mutual funds (financial assets). Similar studies have found income uncertainty to be negatively associated with homeownership and illiquid asset holding (Haurin \& Gill, 1987; Robst et al., 1998). As found in earlier studies, this paper confirms that risk tolerance is a positive predictor of financial asset ownership (Amuedo-Dorantes \& Pozo, 2002; Menchik \& Jianakoplos, 1997) in all three groups. Additionally, the results show that immigrants are less likely to own financial assets than native-born Americans. However, the likelihood of owning financial assets increases among immigrants with the number of years they have lived in the United States. This finding is similar to the results from earlier studies, which reveal that economic participation of immigrants increases with their period of stay in the U.S. (Borjas, 1985).

Table 3

Probit of Financial Asset Ownership

\begin{tabular}{|c|c|c|c|c|c|c|c|c|c|}
\hline \multirow{2}{*}{$\begin{array}{l}\text { Dependent Variable } \\
\mathrm{N}=4822\end{array}$} & \multicolumn{3}{|c|}{ Own Stocks } & \multicolumn{3}{|c|}{ Own Stocks (Native-born) } & \multicolumn{3}{|c|}{ Own Stocks (Immigrant) } \\
\hline & $(1)$ & $(2)$ & (3) & (4) & (5) & (6) & (7) & $(8)$ & (9) \\
\hline Variables & Coef. & Robust S.E. & Sig & Coef. & Robust S.E. & Sig & Coef. & Robust S.E. & Sig \\
\hline Log Income Uncertainty & -0.194 & 0.011 & $* *$ & -0.184 & 0.012 & $* *$ & -0.212 & 0.018 & $* * *$ \\
\hline Immigrant & -0.353 & 0.067 & $* * *$ & & & & & & \\
\hline Age & -0.003 & 0.011 & & -0.008 & 0.017 & & -0.007 & 0.020 & \\
\hline Age Square & 0.000 & 0.007 & & 0.000 & 0.008 & & 0.000 & 0.009 & \\
\hline Married & 0.021 & 0.063 & & 0.046 & 0.065 & & 0.030 & 0.082 & \\
\hline Male & 0.045 & 0.053 & & 0.040 & 0.058 & & -0.052 & 0.092 & \\
\hline Black & -0.359 & 0.060 & $* * *$ & -0.361 & 0.059 & $* * *$ & -0.025 & 0.205 & \\
\hline Hispanic & -0.224 & 0.052 & $* * *$ & -0.225 & 0.055 & $* * *$ & -0.212 & 0.068 & $* *$ \\
\hline Asian & 0.010 & 0.249 & & 0.239 & 0.247 & & 0.001 & 0.266 & \\
\hline Family size & 0.071 & 0.019 & $* * *$ & 0.078 & 0.021 & $* * *$ & 0.057 & 0.041 & \\
\hline Children & -0.325 & 0.053 & $* * *$ & -0.320 & 0.059 & $* * *$ & -0.366 & 0.143 & $* *$ \\
\hline \multicolumn{10}{|c|}{ Education (Ref: $<12$ years) } \\
\hline 12 years & 0.022 & 0.098 & & 0.022 & 0.095 & & 0.029 & 0.157 & \\
\hline $13-15$ years & 0.104 & 0.094 & & 0.104 & 0.090 & & 0.070 & 0.166 & \\
\hline 16 years & 0.256 & 0.109 & $* *$ & 0.258 & 0.106 & $* *$ & 0.219 & 0.194 & \\
\hline$>16$ years & 0.298 & 0.104 & $* *$ & 0.289 & 0.117 & $* *$ & 0.415 & 0.234 & $*$ \\
\hline Log Income & 0.369 & 0.042 & $* * *$ & 0.371 & 0.053 & $* * *$ & 0.229 & 0.112 & $* *$ \\
\hline Risk Tolerance & 0.251 & 0.101 & $* *$ & 0.218 & 0.084 & $* *$ & 0.612 & 0.205 & $* * *$ \\
\hline Inheritance & 0.365 & 0.078 & $* * *$ & 0.360 & 0.150 & $* *$ & 0.609 & 0.400 & \\
\hline \multicolumn{10}{|l|}{ Region (Ref: North East) } \\
\hline North Central & 0.004 & 0.046 & & 0.007 & 0.068 & & -0.063 & 0.217 & \\
\hline South & 0.028 & 0.062 & & 0.019 & 0.068 & & -0.008 & 0.144 & \\
\hline West & 0.047 & 0.054 & & 0.103 & 0.078 & & -0.053 & 0.137 & \\
\hline Years of Stay & & & & & & & 0.334 & 0.018 & $* * *$ \\
\hline Constant & -7.147 & 0.496 & $* * *$ & -5.178 & 0.719 & $* * *$ & -4.232 & 1.402 & $* * *$ \\
\hline $\begin{array}{l}\text { Test of Model fit } \\
\text { Wald Chi-square test }\end{array}$ & 436.11 & $\mathrm{P}>\left|\square^{2}\right|$ & $* * *$ & 431.47 & $\mathrm{P}>\left|\square^{2}\right|$ & $* * *$ & 169.98 & $\mathrm{P}>\left|\square^{2}\right|$ & $* * *$ \\
\hline
\end{tabular}

$* \mathrm{p}<.1, * * \mathrm{p}<.05, * * * \mathrm{p}<.01$ 
Consistent with past findings (Amuedo-Dorantes \& Pozo, 2002; Menchik \& Jianakoplos, 1997; Wang \& Hanna, 1997), income is a positive predictor of stock ownership in the entire population as well as in the native-born and immigrant models. African-Americans are less likely to own stocks when compared with the reference group of Caucasians in the first two models, but the relationship is not significant in the case of immigrants. Hispanics are less likely than Caucasians to participate in financial asset ownership in all three models. The results regarding racial differences are consistent with past studies, which find that minorities have lower stock market participation (Keister, 2000). Having children is negatively associated with owning stocks in all three groups. Previously, studies on household investments have also found that having children lowered the probability of owning financial assets (Springstead \& Wilson, 2000; Zagorsky, 2005). Additionally, the results show that, compared with the reference group who obtained less than 12 years of schooling, those who have an educational attainment of 16 years or more are likely to own financial assets. This relationship was significant across all three models. Inheritance and family size are predictors of stock ownership for the overall model and for native-born Americans; however, this relationship is not significant in the case of immigrants. Earlier studies have also found that inheritance was a predictor of asset ownership (Menchik \& Jianakoplos, 1997).

\section{DISCUSSION}

This paper contributes to the literature on immigrant investment behavior by studying the effect of income uncertainty on financial market participation among U.S. immigrants and native-born residents. Earlier studies have shown that uncertainty of income reduced the likelihood of owning housing assets (Haurin \& Gill, 1987; Robst et al., 1998). The analyses of this paper extend these findings to show that income uncertainty is also a barrier to investment in financial assets.

After controlling for income uncertainty and risk tolerance in the model, the results show that immigrant investors remain less likely than native-born Americans to invest in financial assets. Descriptive statistics as well as the tests of significance provide further evidence that immigrants are less likely than native-born Americans to participate in investment asset ownership. This can probably be explained through immigrants' present lack of access to investment opportunities (Dustmann, 1997). Although the likelihood of financial asset ownership among immigrants increases with their period of stay in the United States, more can be done to encourage immigrant participation in financial markets as a large number of this group approaches retirement. Since a larger percentage of recent immigrants to this country are not Caucasian, the disparity in financial asset ownership may possibly be explained through the cultural differences between the majority of the Caucasian, native-born population and the non-Caucasian, immigrant population. Lower financial market participation seen in this study may also offer some explanation for the lower wealth accumulation of immigrants found in earlier studies (Amuedo-Dorantes \& Pozo, 2002; Carroll et al., 1994).

\section{CONCLUSION}

This paper uses data from NLSY79 to investigate the differences in financial market participation for immigrants and natives (after controlling for risk tolerance and income uncertainty). Lower likelihood of investment in financial assets among respondents facing income uncertainty may result in inadequate savings for retirement. As ownership of investment assets, such as stocks or mutual funds, has been shown to be an important contributor in the wealth accumulation process (Campbell \& Viciera, 2003), continued disparity in financial market participation may perpetuate the existing native-immigrant economic gap. It is therefore important to encourage financial market participation among individual investors. In the future, more comprehensive research including the immigrants' country of origin will be conducted to empirically estimate whether country of origin may also contribute to the differences in economic participation and asset ownership decisions among immigrants.

\section{AUTHOR INFORMATION}

Swarn Chatterjee is an Assistant Professor of financial planning at the University of Georgia. He has a Ph.D. from Texas Tech University. His research interests include economic psychology, economics of immigration, role of income uncertainty and risk tolerance on individual investment decisions. 


\section{REFERENCES}

1. Aizcorbe, A. M., Kennickell, A. B., \& Moore, K. B. (2003). Recent changes in US family finances: Evidence from the 1998 and 2001 Survey of Consumer Finances. Federal Reserve Bulletin, 89(1), 1-32.

2. Amuedo-Dorantes, C., \& Pozo, S. (2002). Precautionary saving by young immigrants and young natives. Southern Economic Journal, 69(1), 48-71.

3. Barsky, R.B, Juster, T.F, Kimball, M.S. \& Shapiro, M.D (1997). Preference parameters and behavioral heterogeneity: An experimental approach in the health and retirement study. Quarterly Journal of Economics, 112, 537-79.

4. Borjas, G. J. (1985). Assimilation, changes in cohort quality, and the earnings of immigrants. Journal of Labor Economics, 3(4), 463-489.

5. Borjas, G. J. (2002). Homeownership in the immigrant population. Journal of Urban Economics, 52(3), 448-476.

6. Campbell, J. Y., \& Viceira, L. M. (2003). Strategic asset allocation. Financial Counseling and Planning, 14(1), 63-65.

7. Carroll, C. D., Rhee, B. K., \& Rhee, C. (1994). Are there cultural effects on saving? Some Cross-sectional evidence. The Quarterly Journal of Economics, 109(3), 685-699.

8. Carroll, C. D., Rhee, B. K., \& Rhee, C. (1999). Does cultural origin affect saving behavior? Evidence from immigrants. Economic Development and Cultural Change, 48(1), 33-50.

9. Chapman, K., Dow, J. P., \& Hariharan, G. (2005). Changes in stockholding behavior: Evidence from household survey data. Finance Research Letters, 2(2), 89-96.

10. Chiswick, B. R. (1978). The Effect of Americanization on the earnings of foreign-born men. The Journal of Political Economy, 86(5), 897-921.

11. Cobb-Clark, D. A., \& Hildebrand, V. A. (2006). The wealth and asset holdings of US-born and Foreignborn households: Evidence from SIPP data. Review of Income and Wealth, 52, 17-42.

12. Dustmann, C. (1997). Return migration, uncertainty and precautionary savings. Journal of Development Economics, 52(2), 295-316.

13. Fu., Y. (1995). Uncertainty, liquidity and housing choices. Regional Science and Urban Economics, 25(2), 223-236

14. Fu., Y. (1991). A model of housing tenure choice: comment. American Economic Review, 81(1), 381-383

15. Haliassos, M., \& Bertaut, C. C. (1995). Why do so few hold stocks? The Economic Journal, 105(432), 1110-1129.

16. Henderson, J.V. \& Ioannides, Y. (1987). Owner occupancy: consumption versus investment demand. Journal of Urban Economics, 21(2), 228-241

17. Henderson, J.V. \& Ioannides, Y. (1983). A model of housing tenure choice. American Economic Review, 73(1), 98-113

18. Haurin, D.R. \& Gill, L.H. (1987). Effects of income variability on the demand for owner-occupied housing. Journal of Urban Economics, 22(2), 136-150.

19. Haurin, D. R., Henderschott, P. H., \& Wachter, S. M. (1996). Borrowing constraints and the tenure choice of young Households. Journal of Housing Research, 8, 137-154.

20. Kazarosian, M. (1997). Precautionary Savings-A Panel Study. Review of Economics and Statistics, 79(2), 241-247.

21. Keister, L. A. (2000). Race and wealth inequality: The impact of racial differences in asset ownership on the distribution of household wealth. Social Science Research, 29(4), 477-502.

22. Lusardi, A. (1998). On the importance of the precautionary saving motive. American Economic Review, 88, 449-54.

23. Menchik, P, L \& Jianakoplos, N, A. (1997). Black-White wealth inequality: Is inheritance the reason? Economic Inquiry, 35(2), 428-442

24. Osili, U. O., \& Paulson, A. (2004). Prospects for Immigrant-Native wealth assimilation: Evidence from financial market participation. Working Paper, Federal Reserve Bank of Chicago, 04-18.

25. Robst, J, Deitz, R. \& McGoldrick, K,M. (1998). Income variability, uncertainty and tenure choice. Regional Science and Urban Economics, 29(2), 219-229

26. Springstead, G. R., \& Wilson, T. M. (2000). Participation in voluntary individual savings accounts: An Analysis of IRAs, 401 (k) s, and the TSP. Social Security Bulletin, 63(1), 34-39. 
27. Wang, H., \& Hanna, S. (1997). Does risk tolerance decrease with age. Financial Counseling and Planning, $8(2), 27-31$.

28. Zagorsky, J. L. (2005). Marriage and divorce's impact on wealth. Journal of Sociology, 41(4), 406.

29. Zagorsky, J. L. (1997). The NLSY79 wealth data evaluation. Columbus, OH: CHRR, The Ohio State University.

30. Zagorsky, J. L. (1999). Young baby boomers' wealth. Review of Income and Wealth, 45(2), 135-156.

\section{NOTES}

